\section{Response to: 'Switching from the bio-originators to biosimilar: is it premature to recommend this procedure?' by Cantini and Benucci}

In their correspondence, Cantini and Benucci ${ }^{1}$ express their concern about the lack of real-life data supporting the switch from originator to biosimilar biological disease-modifying antirheumatic drugs, as recommended in the recently issued consensus-based recommendations. ${ }^{2}$ They argue that the Danish Nationwide Biologic (DANBIO) registry reporting real-life data showed a lower than expected retention rate after the switch to biosimilar infliximab (bio-IFX) and etanercept. ${ }^{34}$

Concerning bio-IFX, several other real-life studies have been published so far. One Dutch and one French open studies have examined real-life outcomes of the switch from originator to bio-IFX in patients with inflammatory rheumatic diseases. ${ }^{5} 6$ Both studies revealed a bio-IFX retention rate between $72 \%$ and $76 \%$, which is lower than the expected originator IFX retention rate. Interestingly, the two studies reported that a significant proportion of patients stopping bio-IFX presented subjective complaints without any clinical sign of disease activity. In the French study, exclusion of the subgroup of patients presenting only subjective complaints (44\% of dropouts) suppressed the difference in retention rate when compared with a historic cohort of original IFX (ori-IFX) treated patients. Finally, both studies allowed patients to switch back to ori-IFX. Patients presenting with subjective complaints were rescued by ori-IFX resumption, whereas those with objective symptoms were more likely to switch to another biologic.

These results strongly suggest that the lower retention rate after the switch is due to a nocebo effect, ${ }^{7}$ or an incorrect attribution bias where a random flare-up is falsely attributed to an unrelated factor (eg, the switch).

To put it in other words, if 100 patients are switched from ori-IFX to bio-IFX, roughly $70 \%$ will continue the biosimilar, $15 \%$ will present IFX failure with objective signs of activity (as expected without the switch) and 15\% will develop subjective symptoms that can be rescued with ori-IFX resumption. Thus, one can see the glass half full or half empty. We prefer to see evidence that in case of switch, $70 \%$ of patients will remain treated with the biosimilar leading to substantial savings for the health system, and that the other 30\% will switch back either to the originator or to another biologic.

We therefore fully support the task force guidelines including recommendation 6 stating that the switch from an originator biologic to its biosimilar appears safe and that this recommendation deserves a $1 \mathrm{~b}$ level of evidence.

Biologics have changed the prognostic of patients with rheumatic diseases. However, this breakthrough has come with substantial costs that our health systems have difficulties to cope with. Biosimilar might be one of the solutions for this serious issue. In the UK, considering that IFX and etanercept are estimated to cost $£ 408$ million/year ( $€ 482$ million) and that biosimilar prices are on average $20 \%$ lower than originator prices, a $70 \%$ biosimilar switch rate would account for savings of 81.6 million/year (€96.4 million). ${ }^{8}$

Biosimilars have, for now, consistently shown that a lower price does not equal a lesser quality. Continuous diffusion, pharmacovigilance and research around biosimilars will allow to address the remaining questions on their use and reassure patients and physicians about their safety.

\section{Marc Scherlinger, Thierry Schaeverbeke}

Department of Rheumatology, Centre Hospitalier Universitaire de Bordeaux, Bordeaux, France

Correspondence to Dr Marc Scherlinger, Department of Rheumatology, Centre Hospitalier Universitaire de Bordeaux, Bordeaux 33076, France; marc.scherlinger@chu-bordeaux.fr

Competing interests None declared.

Provenance and peer review Not commissioned; internally peer reviewed.

(c) Article author(s) (or their employer(s) unless otherwise stated in the text of the article) 2019. All rights reserved. No commercial use is permitted unless otherwise expressly granted.

\section{Check for updates}

To cite Scherlinger M, Schaeverbeke T. Ann Rheum Dis 2019;78:e24.

Received 15 January 2018

Accepted 17 January 2018

Published Online First 26 January 2018

\section{S Linked}

- http://dx.doi.org/10.1136/annrheumdis-2018-213044

Ann Rheum Dis 2019;78:e24. doi:10.1136/annrheumdis-2018-213021

\section{REFERENCES}

1 Cantini F, Benucci M. Switching from the bio-originators to biosimilar: is it premature to recommend this procedure? Ann Rheum Dis 2019;78:e23.

2 Kay J, Schoels MM, Dörner T, et al. Consensus-based recommendations for the use of biosimilars to treat rheumatological diseases. Ann Rheum Dis 2018;77:165-74.

3 Glintborg B, Sørensen IJ, Loft AG, et al. A nationwide non-medical switch from originator infliximab to biosimilar CT-P13 in 802 patients with inflammatory arthritis: 1-year clinical outcomes from the DANBIO registry. Ann Rheum Dis 2017;76:1426-31.

4 Glintborg B, Omerovic E, Danebod K, et al. One-year clinical outcomes in 1623 patients with inflammatory arthritis who switched from originator to biosimilar etanercept - an Observational Study from the Danish Danbio Registry. ACR Meet. Abstr. 2017. http://acrabstracts.org/abstract/one- year-clinical-outcomes-in-1623patients-with-inflammatory-arthritis-who-switched-from-originator-to-biosimilaretanercept-an-observational-study-from-the-danish-danbio-registry/ (accessed $25 \mathrm{Dec}$ 2017).

5 Tweehuysen $L$, van den Bemt BJF, van Ingen IL, et al. Subjective complaints as the main reason for biosimilar discontinuation after open-label transition from reference infliximab to biosimilar infliximab. Arthritis Rheumatol 2018;70:60-8.

6 Scherlinger M, Germain V, Labadie C, et al. Switching from originator infliximab to biosimilar CT-P13 in real-life: the weight of patient acceptance. Joint Bone Spine 2017 doi: 10.1016/j.jbspin.2017.10.003 [Epub ahead of print: 14 Nov 2017].

7 Rezk MF, Pieper B. Treatment outcomes with biosimilars: be aware of the nocebo effect. Rheumatol Ther 2017:4:209-18.

8 NHS Digital. Prescribing costs in hospitals and the community, England 2015/16. http:// digital.nhs.uk/catalogue/PUB22302 (accessed 8 Jan 2018). 